\title{
PENINGKATAN KEMAMPUAN MENULIS TEKS PROSEDUR KOMPLEKS MELALUI MODEL PEMBELAJARAN STAD (STUDENT TEAM ACHIEVEMENT DIVISION) PADA KELAS X-IPA 3 SMAN CANDIPURO LUMAJANG
}

\author{
Anis Dwi Winarsih \\ SMAN Candipuro Lumajang \\ Email : anisdwiwinarsih@gmail.com
}

\begin{abstract}
ABSTRAK
Penelitian ini bertujuan untuk mengetahui hasil belajar siswa pada mata pelajaran bahasa Indoneisa Teks Prosedur Kompleks dengan menggunakan model pembelajaran STAD (Student Team Achievement Division). Penelitian ini dilaksanakan di SMAN Candipuro Lumajang dengan menggunakan pendekatan kuantitatif. Data penelitian ini berupa observasi aktivitas guru, aktivitas siswa dan kemampuan mengerjakan soal dalam bahasa Indonesia tentang Teks Prosedur Kompleks. Data Penelitian bersumber pada peserta didik kelas X-IPA 3 dan observer yang melaksanakan penelitian di sekolah tersebut. Hasil penelitian menunjukkan bahwa model pembelajaran STAD (Student Team Achievement Division) terlaksana dengan baik sesuai dengan sintak pembelajaran yang direncanakan. Kemampuan setiap siswa dalam belajar dan mengajarkan materi/pokok bahasan kepada temannya yang lain dalam kelompok dapat berlangsung dengan baik, sehingga temannya mampu untuk memahami dan memecahkan masalah bahasa Indonesia Teks Prosedur Kompleks dengan baik. Hal ini ditunjukkan dengan peningkatan prosentase belajar siswa dalam menulis teks prosedur kompleks dari 30\% menjadi 83,3\%.
\end{abstract}

Kata Kunci: Kemampuan menulis, teks prosedur kompleks, model pembelajaran STAD

\begin{abstract}
ABTRACT
The research is conducted to find out the result of the students' learning on the Indonesian Complex Procedural Text subject by using STAD (Student Team Achievement Division) learning model. The research is conducted in SMAN Candipuro Lumajang by using quantitative method. The data is collected in the form of observation on the teacher's activity, students' activity, and the ability in solving the test in Indonesian language on Complex Text Procedure. The source of the data is the tenth grader students of natural science stream 3 and the observer who conducted the research on the school. The result of the research is showing the good implementation of STAD learning model in parallel to the planned learning syntax. The students' ability in learning and teaching the material/topic in the groupwork is well conducted in solving the problems within the Complex Text Procedure. The result is evidenced by the increase of the students' learning presentage in writing complex procedural text from $30 \%$ to $83.3 \%$.
\end{abstract}

Keywords:Writing skill, complex text procedure, STAD learning model.

\section{PENDAHULUAN}

Pembelajaran bahasa Indonesia di dunia pendidikan merupakan pelajaran yang mutlak harus diberikan. Hal itu terkait dengan fungsi bahasa Indonesia sebagai

bahasa pemersatu suku-suku di Indonesia, yang tentunya memiliki bahasa daerah masing-masing. Dengan demikian, 
keberadaan bahasa Indonesia bukan sekedar simbol dari negara Indonesia, namun juga warganya harus turut andil dalam melestarikan bahasa Indonesia.

Adanya pemberlakuan kurikulum 2013 seperti menjadi angin segar bagi mata pelajaran bahasa Indonesia. Pada kurikulm 2013, mata pelajaran bahasa Indonesia diberikan empat jam pelajaran setiap minggu. Hal itu untuk menunjang ketercapaian tujuan pembelajaran bahasa Indonesia. Selain itu, adanya materi bahasa Indonesia yang sudah terstruktur dalam kurikulum 2013 menjadikan proses pembelajaran bahasa Indonesia lebih mudah.

Materi pembelajaran bahasa Indonesia yang telah terstruktur, ternyata tidak menjamin bahwa tujuan pembelajaran bahasa Indonesia akan terealisasi secara sempurna. Hal tersebut disebabkab karena tidak didukung dengan kompetensi para pendidik. Kompetensi dan profesionalisme pendidik sangat dibutuhkan untuk menunjang ketercapaian tujuan pembelajaran bahasa Indonesia.

Pada SMAN Candipuro Lumajang, khususnya kelas $\mathrm{X}$ terdapat materi yang sulit dikuasai oleh siswa. Materi yang belum dikuasai tersebut adalah materi menulis teks prosedur pada siswa kelas X SMA. Hal tersebut disebabkan karena guru hanya menggunakan metode ceramah dalam kegiatan pembelajarannya, sehingga siswa kurang antusias mengikuti pembelajaran pada materi menulis teks prosedur. Padahal materi tersebut seharusnya lebih mendorong siswa aktif dan kreatif dalam menuangkan idenya menulis teks prosedur.

Adanya kondisi realitas siswa yang cenderung kurang memperhatikan guru ketika mengajar juga menjadi penyebab tidak tercapainya materi menulis teks prosedur. Siswa terlihat berbicara dengan temannya ketika pelajaran. Hal itu menyebabkan siswa tidak terfokus pada pembelajaran yang dilakukan. Bahkan, ada beberapa siswa yang masih senang bermain gadgetnya selama proses pembelajaran.

Selain itu, kurangnya kemampuan siswa menulis teks prosedur juga disebabkan oleh media yang digunakan guru dalam proses pembelajaran. Guru masih menggunakan media papan tulis untuk menyampaikan materi teks prosedur pada siswa, walaupun sudah disediakan LCD dan projektor.

Berdasarkan paparan tersebut, peneliti memberi judul "Peningkatan Kemampuan Menulis Teks Prosedur Kompleks melalui Model STAD (Student Team Achievement Division) pada Siswa Kelas X-IPA 3 SMAN Candipuro Lumajang”. Tujuan penelitian ini terdiri dari dua hal, yaitu (1) mendeskripsikan penerapan model STAD (Student Team Achievement Division) untuk meningkatkan kemampuan menulis teks prosedur kompleks pada siswa kelas X-IPA 3 SMAN Candipuro Lumajang, dan (2) Mendeskripsikan hasil dari penerapan model STAD (Student TeamAchievement Division) untuk meningkatkan kemampuan menulis teks prosedur kompleks pada siswa kelas X-IPA 3 SMAN Candipuro Lumajang.

Pengertian menulis menurut Huda (2014: 9) adalah proses melahirkan pikiran atau perasaan, seperti mengarang, membuat surat dengan tulisan. Menulis berarti menuangkan isi hati si penulis ke dalam bentuk tulisan, sehingga maksud hati penulis dapat diketahui oleh orang lain melalui tulisan yang dituliskan. Kemampuan seseorang dalam menuangkan isi hatinya ke dalam sebuah tulisan sangatlah berbeda. Hal itu dipengaruhi oleh latar belakang penulis. Dengan demikian, mutu atau 
kualitas tulisan setiap penulis tentu saja berbeda satu sama lain.

Kegiatan menulis sangatlah beragam. Salah satunya menulis teks prosedur kompleks. Teks prosedur kompleks memberikan arahan kepada kita dalam melaksanakan suatu tindakan dengan baik dan benar, sehingga tidak membahayakan diri sendiri ataupun orang lain.

Kosasih (2013: 131) mengatakan bahwa teks prosedur kompleks adalah teks yang yang menjelaskan langkahlangkah secara lengkap dan jelas tentang cara melakukan sesuatu. Selain itu, dalam buku wajib Bahasa Indonesia kelas $\mathrm{X}$ SMA dideskripsikan bahwa teks prosedur kompleks berisi langkah-langkah atau tahap yang harus ditempuh untuk mencapai tujuan. Dengan demikian, keberadaan teks prosedur kompleks sangatlah penting.

Teks prosedur kompleks memiliki dua struktur. Struktur pertama merupakan pendahuluan. Pendahuluan berisi pengantar yang berkaitan dengan petunjuk yang akan dikemukakan pada bagian pembahasan. Struktur yang kedua merupakan pembahasan. Pembahasan berisi petunjuk atau langkahlangkah pengerjaan sesuatu yang disusun secara sistematis. Penyusunannya menngikuti urutan waktu atau bersifat kronologis.

Tiga kategori pembahasan pada isi suatu teks prosedur kompleks menurut Arifyadi (2012: 32) sebagai berikut.

(1) Teks yang berisi cara-cara menggunakan alat, benda ataupun perangkat lain yang sejenis. Contohnya, cara menggunakan komputer dan cara mengendarai mobil secara manual.

(2) Teks yang berisi cara-cara melakukan suatu aktivitas. Contohnya, cara-cara melamar pekerjaan, cara membaca buku secara efektif, cara-cara berolahraga untuk penderita sakit jantung.
(3) Teks yang berisi kebiasaan-kebiasaan atau sifat-sifat tertentu. Contohnya, cara-cara menikmati hidup dan caracara melepaskan kebosanan.

Adanya kenyataan mengenai kurangnya kemampuan siswa kelas X-IPA 3 SMAN Candipuro Lumajang, maka perlu diterapkan sebuah model pembelajaran yang mampu meningkatkan kemampuan siswa kelas X-IPA 3 SMAN Candipuro Lumajang dalam menulis teks prosedur kompleks. Model pembelajaran yang dimaksud ialah STAD (Student Team Achievement Division). STAD (Student Team Achievement Divisions) adalah salah satu tipe pembelajaran kooperatif yang paling sederhana. Siswa ditempatkan dalam tim belajar beranggotakan empat orang yang merupakan campuran menurut kemampuan dan tingkat kerjanya. Kemudian, guru menyajikan pelajaran kemudian siswa bekerja dalam tim untuk memastikan bahwa seluruh anggota tim telah menguasai materi yang diajarkan. Setelah dipastikan seluruh anggota tim menguasai materi, maka seluruh siswa diberi kuis tentang materi itu dengan catatan. Pada saat kuis, mereka tidak diperkenankan saling membantu.

Menurut Slavin (dalam Warsono, 1997: 21) ada lima komponen utama dalam pembelajaran kooperatif metode STAD, yaitu penyajian kelas, pembagian kelompok, tes dan kuis, skor peningkatan individual, dan pengakuan kelompok. Penyajian kelas merupakan penyajian materi yang dilakukan guru secara klasikal dengan menggunakan presentasi verbal atau teks. Penyajian difokuskan pada konsepkonsep dari materi yang dibahas. Pembagian kelompok berfungsi ialah agar saling meyakinkan bahwa setiap anggota kelompok dapat bekerja sama dalam 
belajar. Kelompok yang dibentuk sebaiknya terdiri dari satu siswa dari kelompok atas, satu siswa dari kelompok bawah dan dua siswa dari kelompok sedang. Kemudian pada komponen tes dan kuis, siswa harus menyadari bahwa usaha dan keberhasilan mereka nantinya akan memberikan sumbangan yang sangat berharga bagi kesuksesan kelompok. Skor peningkatan individual berguna untuk memotivasi agar bekerja keras memperoleh hasil yang lebih baik dibandingkan dengan hasil sebelumnya. Skor peningkatan individual dihitung berdasarkan skor dasar dan skor tes. Pada komponen terakhir, pengakuan kelompok dilakukan dengan memberikan penghargaan atas usaha yang telah dilakukan kelompok selama belajar. Kelompok dapat diberi sertifikat atau bentuk penghargaan lainnya jika dapat mencapai kriteria yang telah ditetapkan bersama. Pemberian penghargaan ini tergantung dari kreativitas guru.

Model pembelajaran STAD (Student Team Achievement Divisions) memiliki kelebihan dan kekurangan. Kelebihan model pembelajaran STAD ialah dapat mengembangkan prestasi siswa, baik hasil tes yang dibuat guru maupun tes baku, rasa percaya diri siswa meningkat, siswa merasa lebih terkontrol untuk keberhasilan akademisnya dan memberikan perkembangkan yang berkesan pada hubungan interpersonal di antara anggota kelompok yang berbeda etnis.

Warsono (2013: 24) mengungkapkan bahwa kekurangan dari model pembelajaran STAD (Student Team Achievement Divisions) ada lima. Pertama, apabila guru terlena tidak mengingatkan siswa agar selalu menggunakan keterampilan-keterampilan kooperatif dalam kelompok maka dinamika kelompok akan tampak macet. Kedua, apabila jumlah kelompok tidak diperhatikan, yaitu kurang dari empat, misalnya tiga, maka seorang anggota akan cenderung menarik diri dan kurang aktif saat berdiskusi dan apabila kelompok lebih dari lima maka kemungkinan ada yang tidak mendapatkan tugas sehingga hanya membonceng dalam penyelesaian tugas. Ketiga, apabila ketua kelompok tidak dapat mengatasi konflik-konflik yang timbul secara konstruktif, maka kerja kelompok akan kurang efektif. Keempat, pembelajaran kooperatif bukanlah obat yang paling mujarab untuk memecahkan masalah yang timbul dalam kelompok kecil, adanya suatu ketergantungan, menyebabkan siswa yang lambat berpikir tidak dapat berlatih belajar mandiri. Kelima, pembelajaran kooperatif memerlukan waktu yang lama sehingga target mencapai kurikulum tidak dapat dipenuhi, tidak dapat menerapkan materi pelajaran secara cepat, serta penilaian terhadap individu dan kelompok dan pemberian hadiah menyulitkan bagi guru untuk melaksanakannya.

\section{METODE}

Penelitian ini merupakan penelitian eksperimen yang berbasis penelitian tindakan kelas. Pendektan yang digunakan ialah pendekatan kuantiltif. Jadi, angkaangka yang ada dalam penelitian ini hanya sebagai penjelas mengenai ketercapaian penggunaan model pembelajaran STAD untuk meningkatkan kemampuan menulis teks prosedur kompleks. Penelitian ini dilakukan pada siswa kelas X-IPA 3 SMAN Candipuro Lumajang

Data dalam penelitian ini berupa penggunaan diksi, struktur kalimat dan ejaan, serta kesesuaian struktur isi teks prosedur kompleks. Diksi atau pilihan kata, struktur kalimat dan ejaan, serta kesesuaian struktur isi teks prosedur kompleks diperoleh dari hasil tes siswa. Sumber 
data berasal dari hasil pretes yang diperoleh siswa. Pretes tersebut berupa membuat tes prosedur kompleks. Dengan demikian, guru dapat megetehaui kemampuan awal siswa dalam menyusun teks prosedur kompleks.

Tahap atau siklus penelitian terdiri dari empat tahapan. Tahapan tersebut diantaranya perencanaan, tindakan, pengamatan dan refleksi. Pada perencanaan, peneliti akan melakukan dua siklus, yang masing-masing siklus terdiri dari empat tahapan. Pada tahap kedua yaitu tidakan, model pembelajaran STAD (Student Team Achievement Division) diterapkan pada siswa kelas X-IPA 3 SMAN Candipuro Lumajang. Tahap ketiga, peneliti mengamati data-data yang telah dikumpulkan melalui instrument yang berupa pernyataan verbal dan nonverbal antara guru dan siswa, proses kegiatan belajar mengajar, penerapan metode yang digunakan, dan evaluasi proses. Pada tahap yang terakhir yaitu refleksi, peneliti menganalisis, memaknai, menjelaskan dan menyimpulkan data yang diperoleh dari pengamatan, serta mengaitkan dengan teori yang ada. Siklus dianggap selesai jika mencapai $75 \%$.

\section{HASIL DAN PEMBAHASAN}

Hasil penelitian tindakan diuraikan dalam beberapa tahapan siklus pembelajaran yang dilakukan. Dalam penelitian tindakan ini, pembelajaran dilakukan dalam dua siklus. Siklus satu terdiri dari empat tahap, yaitu perencanaan, pelaksanaan, observasi dan refleksi. Pada tahap perencanaan, peneliti melakukan (1) menyusun Rencana Pelaksanaan Pembelajaran (RPP), (2) menyusun
Lembar Observasi Kinerja Guru dan Aktifitas siswa, (3) menyusun Lembar Kerja Siswa, (4) membuat Instrumen yang digunakan dalam siklus I dan II, dan (5) menyusun Rubrik Penilaian Produk.

Pada tahap pelaksanaan terlihat bahwa guru model belum melakukan kegiatan apersepsi dan belum menyampaikan tujuan yang akan dicapai. Guru juga belum menjelaskan tugas masing-masing kelompok, sehingga siswa masih bingung dengan tugas yang diberikan. Selain itu, Guru masih ragu dalam menjalankan langkah-langkah model pembelajaran STAD.

Setelah model pembelajaran STAD diterapkan, ternyata siswa belum memahami sepenuhnya mengenai struktur dan kaidah kebahasaan teks prosedur kompleks. Ketidakpahaman tersebut dipicu oleh kurangnya kemauan siswa untuk membaca tentang materi yang dierikan. Selain itu, siswa belum maksimal menjalankan diskusi. Hal tersebut terlihat pada tahap observasi.

Refleksi yang dilakukan ialah (1) meningkatkan materi teks prosedur kompleks, sehingga siswa lebih dapat memahami struktur, kaidah kebahasaan, maupun ciri-ciri dari teks prosedur kompleks, (2) mengaktifkan siswa dalam diskusi kelompok, (3) mengajak siswa untuk lebih aktif dalam memberikan tanggapan dalam tanya jawa tentang teks prosedur kompleks, dan (4) memotivasi siswa untuk melaksanakan kerjasama dalam kelompok terhadap materi teks prosedur kompleks. Hal tersebut dibuktikan oleh tabel berikut.

\section{Tabel 1 Prosentase Ketuntasan Kemampuan Penulisan Teks Prosedur Kompleks Siswa Kelas X-IPA 3 SMAN Candipuro Lumajang}

\begin{tabular}{|c|c|c|c|}
\hline TUNTAS & PROSENTASE (\%) & TIDAK TUNTAS & PROSENTASE (\%) \\
\hline 12 & 30 & 24 & 70 \\
\hline
\end{tabular}


Hasil siklus I secara umum dapat yang tuntas sebanyak 12 siswa (30\%). disimpulkan bahwa pada siswa kelas X- Gambaran pencapaian hasil belajar pada IPA 3 SMAN Candipuro Lumajang yang siklus I dapat diperlihatkan melalui data tidak tuntas 24 siswa (70\%), sedangkan berikut.

Tabel 2 Analisis Nilai Tes Siswa X-MIPA 3 SMAN Candipuro Lumajang Siklus I

\begin{tabular}{|c|c|c|c|}
\hline No. & Nama Siswa & Nilai & Keterangan \\
\hline 1 & $\mathrm{AH}$ & 60 & Tidak Tuntas \\
\hline 2 & AA & 58 & Tidak Tuntas \\
\hline 3 & AN & 42 & Tidak Tuntas \\
\hline 4 & AR & 65 & Tidak Tuntas \\
\hline 5 & ARo & 62 & Tidak Tuntas \\
\hline 6 & $\mathrm{AM}$ & 51 & Tidak Tuntas \\
\hline 7 & Amr & 65 & Tidak Tuntas \\
\hline 8 & AAy & 70 & Tuntas \\
\hline 9 & $\mathrm{BE}$ & 73 & Tuntas \\
\hline 10 & CA & 46 & Tidak Tuntas \\
\hline 11 & CAd & 45 & Tidak Tuntas \\
\hline 12 & DV & 72 & Tuntas \\
\hline 13 & DC & 67 & Tuntas \\
\hline 14 & FK & 50 & Tidak Tuntas \\
\hline 15 & FF & 46 & Tidak Tuntas \\
\hline 16 & FA & 72 & Tuntas \\
\hline 17 & FS & 56 & Tidak Tuntas \\
\hline 18 & FM & 41 & Tidak Tuntas \\
\hline 19 & GP & 56 & Tidak Tuntas \\
\hline 20 & KF & 30 & Tidak Tuntas \\
\hline 21 & KM & 36 & Tidak Tuntas \\
\hline 22 & LR & 70 & Tuntas \\
\hline 23 & MAr & 38 & Tidak Tuntas \\
\hline 24 & $\mathrm{MFa}$ & 71 & Tuntas \\
\hline 25 & MFi & 42 & Tidak Tuntas \\
\hline
\end{tabular}

Anis Dwi Winarsih, Peningkatan Kemampuan Menulis Teks Prosedur Kompleks Melalui Metode Pembelajaran STAD (Student Team Achievement Division) pada Kelas X-IPA 3 SMAN Candipuro Lumajang 
Lanjutan Tabel 2

\begin{tabular}{|c|c|c|c|}
\hline No. & Nama Siswa & Nilai & Keterangan \\
\hline 26 & MNa & 68 & Tuntas \\
\hline 27 & MRa & 42 & Tidak Tuntas \\
\hline 28 & NV & 69 & Tuntas \\
\hline 29 & Ot & 80 & Tuntas \\
\hline 30 & RJ & 56 & Tidak Tuntas \\
\hline 31 & RS & 43 & Tidak Tuntas \\
\hline 32 & SCa & 60 & Tidak Tuntas \\
\hline 33 & SAb & 49 & Tidak Tuntas \\
\hline 34 & TGa & 49 & Tidak Tuntas \\
\hline 35 & TAd & 74 & Tuntas \\
\hline 36 & VFi & 69 & Tuntas \\
\hline
\end{tabular}

Hal tersebut mengindikasikan bahwa pemahaman terhadap materi teks prosedur kompleks kurang maksimal. Hanya beberapa anak yang aktif untuk mengajar teman kelompoknya. Selain itu, kurangnya kemampuan merespon hasil presentasi disebabkan kurangnya pemahaman terhadap materi teks prosedur kompleks dan kurangnya kerjasama dalam kelompok.

Prosentase keberhasilan kinerja guru di atas didapat dari hasil laporan kinerja para observer yang dapat dideskripsikan sebagai berikut:

(1) Guru model belum melakukan kegiatan apersepsi.

(2) Guru belum menyampaikan kompetensi / tujuan yang akan dicapai.

(3) Tugas masing-masing kelompok belum dijelaskan secara optimal.

(4) Guru kurang memotivasi siswa untuk bekerjasama dalam satu kelompok.

(5) Guru masih ragu dalam menjalankan langkah-langkah strategi pembelajaran STAD.

(6) Belum adanya penjelasan aktifitas siswa setelah diskusi.
(7) Guru belum melakukan umpan balik, jika tidak ada siswa yang bertanya.

(8) Guru belum melaksanakanan tindak lanjut, misalnya memberikan arahan tugas sebagai bagian dari remidi.

Berdasarkan hasil penilaian observer, maka refleksi yang dapat dilakukan adalah sebagai berikut.

(1) Kegiatan apersepsi perlu dilakukan di awal pembelajaran.

(2) Guru hendaknya menyampaikan kompetensi dan tujuan yang akan dicapai.

(3) Guru harus menjelaskan tugas masingmasing kelompok secara optimal.

(4) Guru memberikan motivasi kepada siswa untuk bekerja sama dalam kelompok.

(5) Guru hendaknya memahami langkahlangkah strategi pembelajaran STAD.

(6) Guru menjelaskan aktifitas siswa setelah diskusi.

(7) Guru memberikan umpan balik, jika tidak ada siswa yang bertanya.

(8) Guru melaksanakanan tindak lanjut, 
misalnya memberikan arahan tugas sebagai bagian dari remidi.

Refleksi yang dilakukan guru untuk mengatasi permasalahan tersebut ialah dengan memberikan penguatan dalam memahami struktur dan kaidah kebahasaan teks prosedur kompleks dengan menanyangkan video animasi mengenai contoh teks prosedur kompleks. Video animasi tersebut berisi struktur dan kaidah kebahasaan dari contoh teks prosedur kompleks yang dibahas.

Adanya kenyataan mengenai belum tercapainya target yang diharapkan, maka peneliti melakukan siklus II. Pada siklus II terdiri dari empat tahapan, yaitu perencanaan, pelaksanaan, observasi dan refleksi.

Pada tahap perencanaan, peneliti menciptakan kondisi pembelajaran yang lebih kondusif, lebih intensif membimbing siswa, memberi kesempatan lebih banyak bertanya kepada siswa dalam menemukan isi dan menyimpulkan teks prosedur kompleks. Selain itu, guru juga memberikan kesempatan yang luas pada siswa untuk mempresentasikan hasil diskusi ahli didepan anggota kelompoknya.

Pada tahap pelaksanaan, guru model dan observer yang berjumlah lima observer melakukan tugas masing-masing sesuai rencana tindakan yang dilakukan. Hasil menunjukkan bahwa siswa sudah tidak bingung lagi dengan tugas yang diberikan, siswa sudah memahami mengenai struktur dan kaidah kebahasaan teks prosedur kompleks, dan respon siswa untuk mempelajarai modul materi yang diberikan sudah mulai terlihat. Hal tersebut terlihat dari tabel berikut.

Tabel 3 Prosentase Ketuntasan Kemampuan Penulisan Teks Prosedur Kompleks Siklus II Siswa Kelas X-IPA 3 SMAN Candipuro Lumajang

\begin{tabular}{|c|c|c|c|}
\hline TUNTAS & PROSENTASE (\%) & TIDAK TUNTAS & PROSENTASE (\%) \\
\hline 30 & 83,3 & 6 & 16,7 \\
\hline
\end{tabular}

Hasil siklus II secara umum dapat disimpulkan bahwa pada siswa kelas XIPA 3 SMAN Candipuro Lumajang yang tuntas 30 siswa (83,3\%), sedangkan yang

tidak tuntas sebanyak 6 siswa (16,7\%). Gambaran pencapaian hasil belajar pada siklus II dapat diperlihatkan melalui data berikut.

Tabel 4 Analisis Nilai Tes Siswa X-MIPA 3 SMAN Candipuro Lumajang Siklus II

\begin{tabular}{|c|c|c|c|}
\hline No. & Nama Siswa & Nilai & Keterangan \\
\hline 1 & AH & 89 & Tuntas \\
\hline 2 & AA & 85 & Tuntas \\
\hline 3 & AN & 98 & Tuntas \\
\hline 4 & AR & 89 & Tuntas \\
\hline 5 & ARo & 90 & Tuntas \\
\hline 6 & AM & 94 & Tuntas \\
\hline 7 & Amr & 66 & Tidak Tuntas \\
\hline
\end{tabular}

Anis Dwi Winarsih, Peningkatan Kemampuan Menulis Teks Prosedur Kompleks Melalui Metode Pembelajaran STAD (Student Team Achievement Division) pada Kelas X-IPA 3 SMAN Candipuro Lumajang 
Lanjutan Tabel 4

\begin{tabular}{|c|c|c|c|}
\hline No. & Nama Siswa & Nilai & Keterangan \\
\hline 8 & AAy & 90 & Tuntas \\
\hline 9 & $\mathrm{BE}$ & 88 & Tuntas \\
\hline 10 & CA & 64 & Tidak Tuntas \\
\hline 11 & CAd & 94 & Tuntas \\
\hline 12 & DV & 90 & Tuntas \\
\hline 13 & DC & 66 & Tidak Tuntas \\
\hline 14 & FK & 86 & Tuntas \\
\hline 15 & $\mathrm{FF}$ & 62 & Tidak Tuntas \\
\hline 16 & FA & 84 & Tuntas \\
\hline 17 & FS & 87 & Tuntas \\
\hline 18 & FM & 90 & Tuntas \\
\hline 19 & GP & 87 & Tuntas \\
\hline 20 & KF & 75 & Tuntas \\
\hline 21 & KM & 65 & Tidak Tuntas \\
\hline 22 & LR & 87 & Tuntas \\
\hline 23 & MAr & 96 & Tuntas \\
\hline 24 & $\mathrm{MFa}$ & 96 & Tuntas \\
\hline 25 & MFi & 86 & Tuntas \\
\hline 26 & $\mathrm{MNa}$ & 89 & Tuntas \\
\hline 27 & MRa & 100 & Tuntas \\
\hline 28 & $\mathrm{NV}$ & 80 & Tuntas \\
\hline 29 & Ot & 88 & Tuntas \\
\hline 30 & RJ & 76 & Tuntas \\
\hline 31 & RS & 66 & Tidak Tuntas \\
\hline 32 & SCa & 87 & Tuntas \\
\hline 33 & $\mathrm{SAb}$ & 95 & Tuntas \\
\hline 34 & TGa & 79 & Tuntas \\
\hline 35 & TAd & 88 & Tuntas \\
\hline 36 & VFi & 89 & Tuntas \\
\hline
\end{tabular}


Berdasarkan tabel di atas, prosentase keberhasilan kinerja siswa dalam memahami teks prosedur kompleks melalui strategi pembelajaran STAD pada siklus II meningkat sebesar 83,3\%. Hasil tersebut mengindikasikan bahwa siswa sudah memahami struktur dan kaidah kebahasaan teks prosedur kompleks karena nilai hasil belajar siswa sudah mengalami peningkatan, meskipun masih ada siswa yang tidak tuntas sebanyak enam orang. Oleh karena itu, dalam tahap refleksi, guru memberikan tindak lanjut kepada siswa yang tidak tuntas. Tindak lanjut tersebut berupa tugas yang dikerjakan di rumah mengenai teks prosedur kompleks.

Prosentase keberhasilan kinerja guru di atas didapat dari hasil laporan kinerja para observer dapat dideskripsikan sebagai berikut:

(1) Guru model sudah melakukan kegiatan apersepsi.

(2) Guru sudah menyampaikan kompetensi/tujuan yang akan dicapai.

(3) Tugas masing-masing kelompok sudah dijelaskan secara optimal.

(4) Guru sudah berusaha memotivasi siswa untuk bekerjasama dalam satu kelompok.

(5) Guru tidak merasa ragu lagi menjalankan langkah-langkah strategi pembelajaran STAD.

(6) Sudah adanya penjelasan aktifitas siswa setelah diskusi.

(7) Guru masih belum melakukan umpan balik, jika tidak ada siswa yang bertanya.

(8) Guru sudah melaksanakanan tindak lanjut, misalnya memberikan arahan tugas sebagai bagian dari remidi.

Berdasarkan hasil penilaian observer, maka refleksi yang dapat dilakukan adalah sebagai berikut.

(1) Guru sudah melakukan perbaikan pada kegiatan apersepsi.
(2) Kompetensi dan tujuan yang akan dicapai sudah tersampaikan dengan runtut.

(3) Guru seharusnya memberikan umpan balik, jika tidak ada siswa yang bertanya.

\section{SIMPULAN}

Berdasarkan hasil penelitian tindakan kelas yang telah dilakukan dapat disimpulkan bahwa penggunaan strategi pembelajaran STAD (Student Team Achievement Division) dapat menciptakan pembelajaran yang menyenangkan, sehingga dapat meningkatkan aktivitas proses pembelajaran siswa khususnya dalam memahami struktur dan kaidah kebahasaan teks prosedur kompleks. Selain itu, juga dapat meningkatkan kemampuan menulis teks prosedur kompleks. Hal tersebut dibuktikan dengan adanya nilai tes yang mengalami peningkatan. Pada siklus I, prosentase hasil belajar siswa sebesar 30\%. Prosentase tersebut mengalami peningkatan pada siklus II, yaitu prosentase hasil belajar siswa sebesar 83,3\%. Dengan demikian, dapat dikatakan bahwa peningkatan prosentase hasil belajar siswa dalam menulis teks prosedur kompleks sebesar 53,3\%.

\section{DAFTAR PUSTAKA}

Ahsan, Arifyadi. 2012. "Model Pembelajaran Kooperatif” (Online). http:// model pembelajaran kooperatif. Blogspot.com/2012/08/student-teamachievement-division-stad_3721. html(diakses tanggal 5 September 2013)

Huda, Miftahul. 2014. Model-model Pengajaran dan Pembelajaran. Pustaka Pelajara: Yogyakarta

Kementerian Pendidikan dan Kebudayaan RI. 2014. Bahasa Indonesia Ekspresi 
Diri dan Akademik. Kementerian Warsono dan Hariyanto. 2013. Pembeajaran Pendidikan dan Kebudayaan: Jakarta Aktif Teori dan Asesmen. Remaja Kosasi, Engkos. 2013. Kreatif Berbahasa Indonesia. Erlangga: Jakarta 